\title{
KADAR LEMAK DAN PROFIL ASAM LEMAK JENUH, ASAM LEMAK TAK JENUH DAGING AYAM BROILER DENGAN PEMBERIAN PAKAN MENGANDUNG TEPUNG DAUN KAYAMBANG (Salvinia molesta)
}

\author{
FAT CONTENT AND SATURATED FATTY ACID PROFILE, UNSATURATED FATTY \\ ACID BROILER CHICKEN MEAT WITH FEEDING CONTAINING KAYAMBANG LEAVES \\ FLOUR (Salvinia molesta)
}

\author{
T. Setiawati, U. Atmomarsono dan B. Dwiloka \\ Fakultas Peternakan dan Pertanian, Universitas Diponegoro, Semarang \\ E-mail: tikasetiasukarnoputri@gmail.com
}

Diserahkan [24 Juli 2016]; Diterima [23 Agustus 2016]; Dipublikasi [31 Agustus 2016]

\begin{abstract}
This study was aimed to determined fat content and saturated fatty acid profile (SFA), unsaturated fatty acid profil (PUFA and MUFA) broiler chicken meat feeding with kayambang leaf flour (Salvinia molesta). This research used 100 broiler chickens at 15 days old unsex with average weight $500 \pm 6,99 \mathrm{~g}$. This research used Completely Randomized Design. Ration treatments arranged for starter and finisher periods. Ration treatments were TO (ration without Salvinia molesta leaf meal); T1 (ration with Salvinia molesta leaf meal 6\%); T2 (ration with Salvinia molesta leaf meal 12\%); and T3 (ration with Salvinia molesta leaf meal 18\%). The fat content data obtained were analyzed using Analysis of Variance at significance level of 5\%. The fatty acid profile data were analyzed using descriptive quantitative analysis. The results showed that Salvinia molesta leaf meal treatment in broiler diet didn't affect significantly $(P<0.05)$ of fat content of the meat. Fatty acid profile showed amount of saturated fatty acids decreased from TO to T3 of the amount of saturated fatty acids $53.21 \%$ to $24.57 \%$ and the amount of unsaturated fatty acids increased from $39.94 \%$ to $68.79 \%$ from TO to T3. Based on the results of the present study it was concluded that Salvinia molesta leaf meal can to reduce the content of saturated fatty acid and increasing the content of unsaturated fatty acid.
\end{abstract}

Keywords: broiler chicken, Salvinia molesta, saturated fatty acid, unsaturated fatty acid

\begin{abstract}
ABSTRAK
Penelitian ini bertujuan untuk mengetahui kadar lemak dan profil asam lemak jenuh (SFA), asam lemak tidak jenuh (PUFA dan MUFA) daging ayam broiler yang diberi pakan tepung daun kayambang (Salvinia molesta). Penelitian ini menggunakan 100 ekor ayam broiler unsex dengan umur perlakuan 15 hari yang memiliki bobot badan $500 \pm 6,99$ g. Penelitian ini menggunakan Rancangan Acak Lengkap (RAL) dengan 4 perlakuan dan 5 ulangan. Ransum perlakuan disusun untuk periode starter dan finisher. Ransum perlakuan adalah T0 (ransum tanpa tepung daun Salvinia molesta); T1 (ransum dengan tepung daun Salvinia molesta) 6\%) ; T2 (ransum dengan tepung daun Salvinia molesta 12\%); dan T3 (ransum dengan tepung daun Salvinia molesta 18\%). Data kadar lemak daging yang diperoleh kemudian dianalisis menggunakan analisis ragam (Analysis of Variance) pada taraf signifikansi 5\% dan data profil asam lemak dianalisis secara deskriptif kuantitatif. Hasil penelitian menunjukkan bahwa perlakuan tepung daun Salvinia molesta dalam ransum ayam broiler tidak memberikan pengaruh secara nyata $(\mathrm{P}<0,05)$ terhadap kadar lemak daging. Profil lemak daging menunjukkan bahwa perlakuan tepung daun Salvinia molesta dalam ransum ayam broiler menunjukkan jumlah asam lemak jenuh mengalami penurunan dari T0 ke T3 dari jumlah asam lemak jenuh 53,21\% menjadi 24,57\% dan jumlah asam lemak tak jenuh mengalami kenaikan dari 39,94\% menjadi 68,79\% dari T0 ke T3. Bedasarkan hasil penelitian disimpulkan bahwa tepung daun Salvinia molesta dalam ransum mampu menurunkan kandungan asam lemak jenuh dan meningkatkan kandungan asam lemak tak jenuh daging ayam broiler.
\end{abstract}

Kata kunci: ayam broiler, Salvinia molesta, lemak, asam lemak 


\section{PENDAHULUAN}

Daging ayam broiler diandalkan sebagai sumber protein hewani yang utama. Tingginya permintaan daging ayam broiler seiring semakin meningkatnya kesadaran masyarakat akan pentingnya mengkosumsi pangan protein hewani yang banyak dibutuhkan untuk metabolisme tubuh. Ayam broiler merupakan salah satu jenis ayam yang banyak dibudidaya karena pertumbuhannya yang sangat cepat. Pertumbuhan yang cepat pada ayam broiler diikuti pula oleh pertumbuhan lemak. Komposisi utama daging broiler adalah asam lemak jenuh yaitu asam lemak yang tidak memiliki ikatan rangkap. Asupan lemak jenuh ke dalam tubuh manusia dalam jumlah banyak akan meningkatkan total kolesterol darah yang nantinya akan meningkatkan kejadian aterosklerosis dan selanjutnya akan meningkatlan resiko penyakit arteri koroner (Sulistyowati, 2009). Sejalan dengan meningkatnya pengetahuan tentang pengaruh asam lemak tertentu pada kandungan lemak darah, lemak hewan ternyata tidak direkomendasikan karena terlalu banyak mengandung asam lemak jenuh (SFA/ Saturated Fatty Acid) dan terlalu sedikit asam lemak tak jenuh (PUFA/Poly Unsatured Fatty Acid). Di samping itu, pentingnya PUFA n-3 telah lama diketahui sehingga n-3 menjadi penting (Leibetseder, 1997).

Penelitian dalam upaya menurunkan kandungan asam lemak jenuh pada daging ayam broiler sudah beberapa kali di lakukan oleh peneliti, seperti adanya penambahan kunyit pada pakan ternak, penambahan jahe merah, dan lain lain, namun masih sedikit yang meniliti tentang menurunkan kandungan asam lemak jenuh. Upaya untuk meningkatkan kandungan omega-3 pada daging yaitu dengan memberikan pakan tambahan yang tidak mengganggu pencernaan dan mengandung omega-3 salah satunya adalah salvinia molesta.

Salvinia molesta (Kayambang) adalah tanaman apung yang bebas di air. Tanaman ini telah banyak menarik perhatian para peneliti untuk mengembangkan manfaat dari
Salvinia molesta. Daun tanaman ini memiliki kandungan zat aktif omega 3. Kadar lemak pada daun cukup tinggi yaitu $6,19 \%$ dibandingkan tanaman air lainya, dimana cadangan lipid oleh lipase dihidrolisis menjadi gliserol dan asam lemak. Kandungan tepung Daun Salvinia molesta sebagai tanaman paku air memiliki protein kasar 16,64\%, lemak kasar 6,19\%, serat kasar 9,50\%, dan energi $3.900 \mathrm{kkal} / \mathrm{kg}$ (Agung et al., 2007).

Penelitian Mukherejee et al., (2010) menemukan bahwa di dalam tanaman air Salvinia molesta mengandung zat omega tiga sebanyak 1,4\% dari kandungan lemak kasar pada daun dan juga mengandung lebih banyak asam lemak tak jenuh (PUFA) yang lebih dibutuhkan manusia daripada kandungan asam lemak jenuhnya (SFA). Saleh et al., (2009) menyatakan bahwa minyak ikan pada ransum ayam broiler yang mengandung omega 3 mampu menurunkan kandungan asam lemak jenuh dan meningkatkan kandungan asam lemak tak jenuh rantai panjang pada daging.

Penggunaan Salvinia molesta yang mengandung omega-3 dalam pakan akan mempengaruhi metabolisme nutrien terutama lemak, karena adanya asam lemak rantai panjang yang terdapat di dalam Salvinia molesta yang dapat menurunkan kadar lemak dan kolesterol darah ayam broiler. Coetzee dan Hoffman (2002) menyatakan bahwa peningkatan level asam lemak omega-3 pada pakan efektif untuk mereduksi asam lemak jenuh pada karkas dan lemak abdominal ayam broiler.

Penelitian ini bertujuan untuk mengetahui pengaruh penggunaan tepung daun Salvinia molesta dalam ransum ayam broiler terhadap kadar lemak dan profil asam lemak jenuh (SFA), asam lemak tidak jenuh (PUFA dan MUFA) pada daging ayam broiler, sehingga menghasilkan daging yang sehat untuk dikonsumsi manusia.

\section{METODE}

Penelitian ini menggunakan bahan ayam broiler strain Lohman unsexing dengan umur 15 hari sebanyak 100 ekor dengan 
bobot badan rata-rata $500 \pm 6,99 \mathrm{~g}$. Ransum perlakuan dengan bahan dasar meliputi jagung kuning, tepung daun Salvinia molesta, bungkil kedelai, bekatul, minyak, tepung ikan, kapur, premix, lysin dan methionin. Ransum perlakuan menggunakan ransum iso protein dan iso energi yang meliputi ransum untuk periode starter yang mengandung PK 20\% dan EM $2.900 \mathrm{kkal} / \mathrm{kg}$ selama seminggu (Tabel 1), dan ransum untuk periode finisher yang mengandung PK $19 \%$ dan EM $2.900 \mathrm{kkal} / \mathrm{kg}$ sampai umur 42 hari (Tabel 2). Air minum diberikan secara adlibitium dan selama penelitian diberikan vaksin ND La Sota tetes mata dan Vaksin Gumboro melalui tetes mata. Tepung daun Salvinia molesta dibuat dengan memisahkan antara daun dan akar, kemudian daun dikeringkan dan kemudian digiling sehingga menjadi tepung.

Tabel 1. Komposisi Ransum dan Kandungan Nutrisi Untuk Periode Starter

\begin{tabular}{lrrrr}
\hline \multicolumn{1}{c}{ Bahan Pakan } & T0 $(0 \%)$ & T1 $(6 \%)$ & T2 $(12 \%)$ & T3 $(18 \%)$ \\
\hline Jagung & 52,10 & 52,30 & 51,00 & 51,80 \\
Bungkil Kedelai & 21,30 & 17,00 & 14,00 & 10,80 \\
Minyak & 1,20 & 1,20 & 1,30 & 1,30 \\
Bekatul & 16,80 & 15,90 & 15,10 & 11,80 \\
Tepung Ikan & 5,00 & 5,00 & 5,00 & 5,00 \\
CaCo & 0,80 & 0,70 & 0,40 & 0,40 \\
Premix & 0,80 & 0,70 & 0,40 & 0,30 \\
Methionin & 1,00 & 0,60 & 0,40 & 0,30 \\
Lisin & 1,00 & 0,60 & 0,40 & 0,30 \\
Tepung Salvinia & 0,00 & 6,00 & 12,00 & 18,00 \\
Total & 100,00 & 100,00 & 100,00 & 100,00 \\
Kandungan nutrisi : & & & & \\
EM (kkal/kg)** & $2.900,71$ & $2.900,84$ & $2.900,31$ & $2.900,80$ \\
PK (\%)* & 20,32 & 20,04 & 20,27 & 20,33 \\
LK (\%)* & 5,04 & 4,94 & 4,91 & 4,68 \\
SK (\%)* & 6,76 & 7,37 & 8,02 & 8,11 \\
Methionin(\%)*** & 1,10 & 0,70 & 0,50 & 0,41 \\
Lisin(\%)*** & 1,39 & 0,98 & 0,78 & 0,66 \\
Kalsium(\%)*** & 1,24 & 1,17 & 0,90 & 0,93 \\
Fosfor(\%)*** & 0,72 & 0,69 & 0,66 & 0,61 \\
\hline
\end{tabular}

\footnotetext{
* Hasil Analisis Proksimat Laboratorium Ilmu Nutrisi dan Makanan Ternak Fakultas Peternakan dan Pertanian, Universitas Diponegoro

** Hasil perhitungan berdasarkan rumus Balton (Siswohardjono, 1982) EM = 40,81 \{0,87 [Protein kasar $+2,25$ Lemak kasar + BETN] +2,5\}

*** Tabel Komposisi Bahan Pakan NRC (1994)
}

Parameter yang diamati meliputi kadar lemak daging, profil asam lemak jenuh yang meliputi SFA dan juga asam lemak tidak jenuh yang meliputi PUFA dan MUFA pada daging ayam broiler yang diberikan perlakuan. Parameter diteliti dengan cara mengambil daging karkas (dada, sayap, paha) sebanyak 50 gram pada akhir penelitian, kemudian digilling supaya homogen dan di ukur dengan menggunakan metode Soxlet's dan dianalisis dengan Kromatografi gas.

Rancangan percobaan yang digunakan adalah Rancangan Acak Lengkap (RAL), dengan 4 perlakuan dan 5 ulangan, sehingga terdapat 20 unit percobaan. Perlakuan yang diterapkan adalah T0: ransum tanpa tepung daun Salvinia molesta; T1: ransum dengan tepung daun Salvinia molesta 6\%; T2: ransum dengan tepung daun Salvinia molesta 
12\%; dan T3: ransum dengan tepung daun

Salvinia molesta $18 \%$.

Tabel 2. Komposisi Ransum dan Kandungan Nutrisi Untuk Periode Finisher

\begin{tabular}{|c|c|c|c|c|}
\hline Bahan Pakan & T0 $(0 \%)$ & $\mathrm{T} 1(6 \%)$ & $\mathrm{T} 2(12 \%)$ & $\mathrm{T} 3(18 \%)$ \\
\hline Jagung & 54,00 & 52,90 & 52,60 & 52,50 \\
\hline Bungkil Kedelai & 19,30 & 16,50 & 12,70 & 9,40 \\
\hline Minyak & 1,20 & 1,10 & 1,20 & 1,20 \\
\hline Bekatul & 17,70 & 17,60 & 16,40 & 14,60 \\
\hline Tepung Ikan & 4,00 & 3,50 & 3,50 & 3,50 \\
\hline $\mathrm{CaCo} 3$ & 1,00 & 0,70 & 0,40 & 0,20 \\
\hline Premix & 1,00 & 0,50 & 0,40 & 0,20 \\
\hline Methionin & 0,90 & 0.60 & 0,40 & 0,20 \\
\hline Lisin & 0,90 & 0,60 & 0,40 & 0,20 \\
\hline Tepung Salvinia & 0,00 & 6,00 & 12,00 & 18,00 \\
\hline Total & 100,00 & 100,00 & 100,00 & 100,00 \\
\hline \multicolumn{5}{|l|}{ Kandungan } \\
\hline \multicolumn{5}{|l|}{ Nutisi : } \\
\hline $\mathrm{EM}(\mathrm{kkal} / \mathrm{kg})^{* *}$ & $2.902,62$ & $2.901,51$ & $2.901,97$ & $2.902,10$ \\
\hline $\mathrm{PK}(\%)^{*}$ & 19,02 & 19,14 & 19,03 & 19,12 \\
\hline $\operatorname{LK}(\%) *$ & 5,09 & 4,91 & 4,87 & 4,71 \\
\hline SK $(\%)^{*}$ & 6,86 & 7,66 & 8,2 & 8,6 \\
\hline $\operatorname{Metionin}(\%) * * *$ & 1,00 & 0,70 & 0,5 & 0,31 \\
\hline $\operatorname{Lisin}(\%) * * *$ & 1,28 & 0,99 & 0,78 & 0,57 \\
\hline Kalsium $(\%) * * *$ & 1,36 & 1,06 & 0,79 & 0,62 \\
\hline Fosfor $(\%) * * *$ & 0,68 & 0,66 & 0,62 & 0,59 \\
\hline
\end{tabular}

* Hasil Analisis Proksimat Laboratorium Ilmu Nutrisi dan Makanan Ternak Fakultas Peternakan dan Pertanian, Universitas Diponegoro

** Hasil perhitungan berdasarkan rumus Balton (Siswohardjono, 1982) EM = 40,81 \{0,87 [Protein kasar $+2,25$ Lemak kasar + BETN] +2,5\}

*** Tabel Komposisi Bahan Pakan NRC (1994)

Data kadar lemak daging yang diperoleh dianalisis menggunakan analisis ragam (Analysis of Variance) pada taraf signifikansi $5 \%$ dan profil asam lemak dianalisis secara deskriptif non parametrik, yaitu dengan cara menggambarkan jumlah kandungan masing-masing asam lemak jenuh dan tidak jenuh pada setiap perlakuan yang di sajikan dalam bentuk tabel atau grafik. Hasil analisis yang telah diperoleh akan dibandingan dengan pustaka.

\section{HASIL DAN PEMBAHASAN}

Hasil penelitian kadar lemak karkas ayam broiler masing masing perlakuan pemberian tepung kayambang (Salvinia molesta), terdapat pada Tabel 3.
Tabel 3. Kadar Lemak Karkas Ayam Broiler dengan Perlakuan Tepung Kayambang (Salvinia molesta)

\begin{tabular}{cc}
\hline \hline Perlakuan (\%) & Rataan Kadar lemak (\%) \\
\hline 0 & $7,046 \pm 1,22$ \\
6 & $5,802 \pm 0,66$ \\
12 & $5,896 \pm 0,58$ \\
18 & $6,170 \pm 0,86$ \\
\hline
\end{tabular}

Keterangan: Nilai rataan menunjukkan tidak berbeda nyata $(\mathrm{P}>0,05)$

Analisis ragam rataan kadar lemak karkas ayam broiler menunjukkan bahwa tepung kayambang (Salvinia molesta) tidak berpengaruh nyata $(\mathrm{P}>0,05)$ terhadap kadar lemak karkas ayam broiler, ketidakmampuan tepung kayambang dalam menurunkan kadar lemak karkas dikarenakan konsumsi pakan per hari untuk masing masing perlakuan juga 
tidak berbeda nyata yaitu $\mathrm{T} 0=118,07$ $\mathrm{g} / \mathrm{ek} / \mathrm{hr}, \mathrm{T} 1=120,77 \mathrm{~g} / \mathrm{ek} / \mathrm{hr}, \mathrm{T} 2=120,35$ $\mathrm{g} / \mathrm{ek} / \mathrm{hr}, \mathrm{T} 3=118,11 \mathrm{~g} / \mathrm{ek} / \mathrm{hr}$ sehingga menghasilkan pembentukan lemak yang tidak berbeda. Kandungan lemak kasar ransum yang ditambah dengan tepung kayambang (Salvinia molesta) memilik jumlah yang tidak jauh berbeda untuk setiap perlakuan (Tabel 1 dan 2).

Kandungan lemak karkas (Ilustrasi 1) selaras dengan pembentukan atau jumlah bobot lemak abdominal yang juga menunjukkan hasil yang tidak berbeda nyata dari kontrol ke perlakuan $(\mathrm{T} 1=27,8 \mathrm{~g}, \mathrm{~T} 2=$ 20,2 g, T3= 23,2 g. T4=17,6 g). Kandungan lemak karkas juga dipengaruhi oleh kandungan trigliserida. Pada hasil penelitian trigliserida tidak mengalami penurunan nyata $(\mathrm{T} 0=41,79 \mathrm{c}, \quad \mathrm{T} 1=54,18 \mathrm{a}, \quad \mathrm{T} 2=46,62 \mathrm{~b}$, $\mathrm{T} 3=38,97 \mathrm{c}$ ) sehingga menghasilkan kandungan lemak karkas yang tidak berbeda di masing masing perlakuan. Menurunnya kandungan trigliserida dalam darah berkorelasi positif dengan menurunkan lemak karkas dan juga lemak abdominal begitu juga sebaliknya. Menurut Murray et al. (2003) lemak utama yang disimpan di dalam jaringan adalah trigliserida, dimana 95 $\%$ Trigliserida berasal dari ransum dan $5 \%$ dari sintesis tubuh. Hermier (1997) menyatakan bahwa semakin rendah kandungan trigliserida dalam darah, rendah pula untuk kadar lemak jaringan dan kadar lemak abdominal. Efek penambahan tepung kayambang yang mengandung zat aktif omega 3 yang merupakan golongan PUFA memiliki sifat mudah teroksidasi sehingga dapat menurunkan sintesa asam lemak, penurunan proses pembentukan lemak (lipogenesis) dan peningkatan pemecahan lemak (lipolisis) sehingga berperan dalam penurunan simpanan lemak di jaringan adiposa.

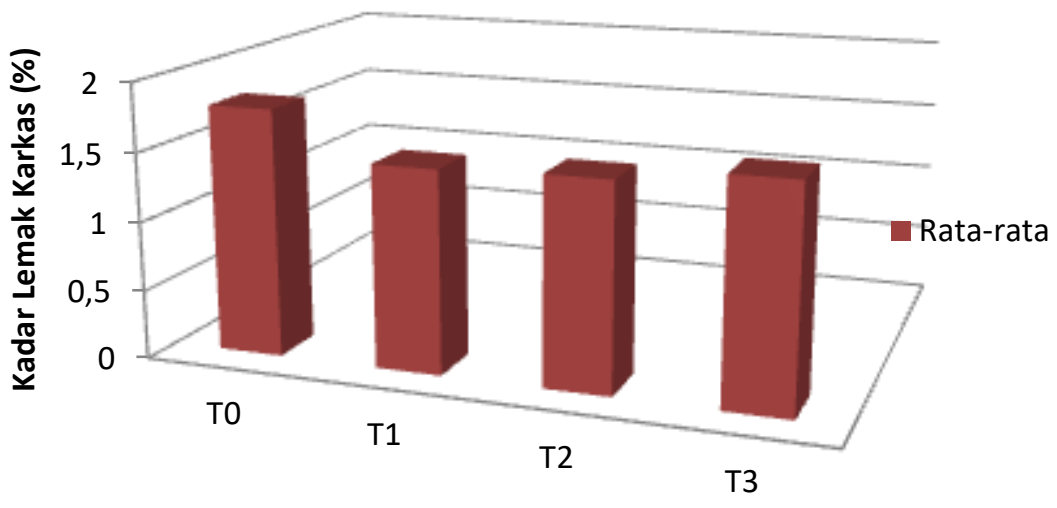

Perlakuan

Ilustrasi 1. Pengaruh Perlakuan terhadap Kadar Lemak Karkas Broiler

Berdasarkan hasil penelitian didapatkan Profil SFA (Saturated Fatty Acid) dan Profil PUFA (Polysaturated Fatty Acid) dan MUFA (Monosaturated Fatty Acid) dari karkas ayam broiler masing masing perlakuan pemberian tepung kayambang (Salvinia molesta), terdapat pada Tabel 3. Tabel 3 menunjukkan jenis asam lemak jenuh dan tidak jenuh beserta total kandungannya. Pada total asam lemak jenuh dari perlakuan T0 ke T3 mengalami penurunan dari 53,21\% menjadi $24,57 \%$ dan begitu juga selaras dengan terjadinya kenaikan pada total asam lemak tak jenuh dari T0 ke T3 yaitu dari 39,94\% menjadi $68,79 \%$, Pada T1 dan T2 asam lemak jenuh terjadi kenaikan dari 53,76\% menjadi 56,37 dan penurunan asam lemak tak jenuh 40,43 menjadi 35,34 (Ilustrasi 2). 
Tabel 4. Profil Asam Lemak Karkas Broiler dengan Perlakuan Tepung Kayambang (Salvinia molesta)

\begin{tabular}{lrrrr}
\hline \multirow{2}{*}{\multicolumn{1}{c}{ Asam Lemak }} & \multicolumn{4}{c}{ Perlakuan } \\
\cline { 2 - 5 } & \multicolumn{1}{c}{ T0 } & T1 & T2 & \multicolumn{1}{c}{ T3 } \\
\hline \multicolumn{1}{c}{ Asam Lemak Jenuh : } & & & \\
Asam Laurat (C12:0) & 0,14 & 0,13 & 0,16 & 0,11 \\
Asam Miristast (C14:0) & 0,76 & 0,72 & 0,74 & 0,80 \\
Asam Palmitat (C16:0) & 22,23 & 20,70 & 22,74 & 23,17 \\
Asam Stearat (C18:0) & 29,49 & 36,13 & 31.92 & 0,00 \\
Asam Arakhidat (C20:0) & 0,59 & 0,29 & 0,81 & 0,49 \\
\hline \multicolumn{1}{c}{ Total } & 53,21 & 57,97 & 56,37 & 24,57 \\
\hline Asam Lemak Tak & & & & \\
Jenuh & & & & \\
Asam Palmitoleat(C16:1) & 7,01 & 5,63 & 17,0 & 6,58 \\
Asam Oleat (C18:1) & 22,40 & 25,76 & 9,63 & 23,05 \\
Asam Linoleat (C18:2) & 9,65 & 8,21 & 0,63 \\
Asam Linolenat (C18:3) & 0,54 & 0,51 & 0,34 & 0,30 \\
Eicosapentaenoal (C20:5) & 0,34 & 0,32 & 0,39 & 0,20 \\
\hline \multicolumn{1}{c}{ Total } & 39,94 & 40,43 & 35,34 & 68,79 \\
\hline
\end{tabular}

Penambahan tepung kayambang (Salvinia molesta) yang mengandung zat aktif omega 3 yang merupakan salah satu jenis asam lemak tak jenuh rantai panjang pada ransum mampu menurunkan kandungan Asam Lemak Jenuh dan Meningkatkan kandungan asam lemak tak jenuh pada karkas ayam Broiler. Saleh et al., (2009) menyatakan bahwa Manipulasi penambahan PUFA mampu menghasilkan penyerapan yang lebih baik di usus, sehingga PUFA dapat dideposisikan ke dalam jaringan meningkat. Penelitian Saleh et al., (2009) menyatakan bahwa modifikasi penambahan bahan pakan yang mengandung Asam lemak tak jenuh baik PUFA maupun MUFA mampu menurunkan asam lemak jenuh dan menaikkan C20:5 (EPA/Asam Eicosapentaenoal), C22:6 (DHA/ Asam Decosahexaenoat), (LNA/Asam Lenolenat) dan omega 3 , sehingga mampu menaikkan PUFA secara signifikan $\quad(p>0,01)$ dibandingkan kontrol.

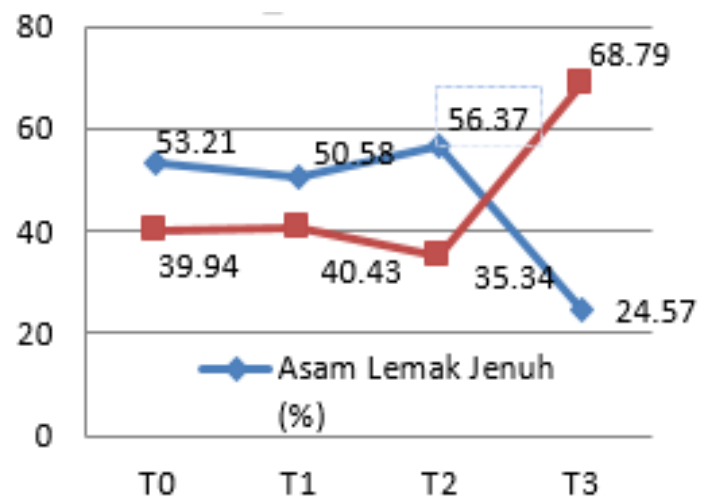

Ilustrasi 2. Pengaruh Perlakuan terhadap Jumlah Kandungan Asam Lemak

Menurut Ratnayake et al. (1993) yang disitasi oleh Eduardo et al. (2013) lemak di broiler daging putih mengandung 33,5\% dari asam lemak jenuh dan $62,5 \%$ dari asam lemak tak jenuh yang terdiri dari 30,5\% tak jenuh ikatan tunggal (MUFA) dan 32\% dari asam lemak tak jenuh ganda (PUFA). Pada perlakuan pemberian tepung kayambang 18 
\% mampu menghasilkan SFA yang lebih rendah dari pada rata rata yaitu $24,57 \%$ dan menghasilkan asam lemak tak jenuh (PUFA dan MUFA) yang lebih tinggi dibandingkan rata-rata yaitu $68,79 \%$. Menurunnya kandungan SFA pada T3 berasal dari asam stearat (C18:0) yang tidak terdapat pada karkas perlakuan tersebut. Asam stearat dalam asam lemak jenuh kurang baik untuk kesehatan, keberadaan Asam Stearat memacu meningkatnya LDL dan kolesterol dalam darah. Sulistyowati (2009) menyatakan bahwa asam lemak jenuh contoh asam stearat dalam asupan yang banyak, secara signifikan mampu meningkatkan kadar kolesterol darah dan LDL darah, asam ini terdapat dalam produk hewani seperti susu, krim, keju, daging berlemak. Dalam Asam lemak Tak Jenuh terdapat Asam Linoleat (C18:2) (Tabel 4) yang meningkat pada perlakuan T3 yaitu pada angka 23,05 $\%$, Asam Linoleat merupakan asam lemak essensial dimana asam lemak yang tidak dapat diproduksi oleh tubuh dan harus mendapatkan asupannya dari makanan.

\section{KESIMPULAN}

Penambahan tepung kayambang (Salvinia molesta) ke dalam ransum ayam broiler sampai pada level $18 \%$ belum mampu menurunkan kadar lemak daging tetapi mampu menurunkan kandungan asam lemak jenuh dan menaikkan kandungan asam lemak tidak jenuh sehingga menghasilkan daging yang lebih sehat untuk dikonsumsi konsumen.

\section{DAFTAR PUSTAKA}

Agung, M. U. K., K. Haetami dan Y. Mulyani. 2007. Penggunaan Limbah Kiambang Jenis duckweeds dan Azola dalam Pakan dan Implikasinya Pada Ikan Nilem. Fakultas Perikanan dan Ilmu Kelautan. Laporan Penelitian Penelitian Dasar (Litsar) Universitas Padjadjaran, Bandung.
Coetzee, G. J. M dan L. C. Hoffman. 2002. Effect of Various Dietary n-3/n-6 Fatty Acid Ratios on The Performance and Body Composition of Broilers. South African J. Anim Sci. 32 : 175 - 184.

Eduardo, J. Morales, J. Mariano, A.Gonzalez, M. Rosa, D. Castillo, F. Omar, R. Prado, L. Xochit, V. Hernandez, M. Anita, T. Guillermo, M.H. Billy, Silvia, dan D. Carrillo. 2013. Fatty Acid Deposition on Broiler Meat in Chickens Pupplemented with Tuna Oil. Food and Nutr. Sci. 4: $16-$ 20.

Hermier, D. 1997. Lipoprotein Metabolism and Fattening in Poultry. J. Nutr. 127: $805 \mathrm{~S}-808 \mathrm{~S}$

Leibetseder J. 1997. The Effect of Nutrition on The Composition of Animal Fat. Anim. Res. Dev. 45 : 46 - 58.

Murray, K. Robert, K. Daryl, A.M. Peter, W.R. Viictor. 2003. Biokimia Harper Edisi 25. EGC. Jakarta. (Penerjemah: Andi Hartoko)

Mukherjee, A. K., P. Kalita, B.G. Unni, S.B.Wann, D. Saikia, and P.K. Mukhopadhyay. 2010. Fatty Acid Composition of Four Potential Aquatic Weeds and Their Possible Use as Fish Feed Neutraceuticals. Food. Chem. 123: 1252 - 1254.

Saleh, H., S.H., K. Rahimi, M.A. Torshizi,. 2009. The Effect of Diet That Contained Fish Oil on Performance, Serum Parameters, The Immune System and The Fatty Acid Composition of Meat in Broilers. Int.J.Vet.Res. 3 (2) : $69-75$

Sulistyowati, T. 2009. Efek Asam lemak jenuh dan asam lemak tak jenuh "trans" terhadap kesehatan. Media Peneliti dan Pengembang Kesehatan. 19 : $13-20$.

Siswohardjono, W. 1982. Beberapa Metode Pengukuran Energi Metabolis Bahan Makanan Ternak pada Itik. Makalah Seminar Fakultas Pasca Sarjana, Institut Pertanian Bogor, Bogor. 
